\title{
Variability of somatic embryogenic ability in the genus Pisum L: effects of genotype, explant source and culture medium
}

\author{
J Loiseau, C Marche, Y Le Deunff * \\ Laboratoire de physiologie végétale appliquée, ENSH, 4, rue Hardy, RP 914, F-78009 Versailles cedex, France
}

(Received 5 January 1996; accepted 15 April 1996)

\begin{abstract}
Summary - The ability of shoot apices, immature cotyledons and embryonic axes excised from mature seeds to express somatic embryogenesis was tested in nine garden peas, eleven field peas, two forage peas and seven species or subspecies other than Pisum sativum L. Embryonic axes were poorly embryogenic when compared to the two other explants. Shoot apices and immature cotyledons were both cultured on two media differing in their sugar composition. Seven garden peas out of nine were more embryogenic than all the field peas. Many genotypes, 22 out of 29 , produced more embryos in cultures of shoot apices when fructose substituted sucrose. With immature cotyledons, somatic embryogenesis was also enhanced for 20 genotypes out of 29 on maltose-supplemented medium compared to sucrose-containing medium. Thus, exogenous carbohydrate seemed to play an essential role in somatic embryogenesis in pea.
\end{abstract}

pisum / somatic embryogenesis / genotype / carbohydrate

Résumé - Variabilité de l'aptitude à l'embryogenèse somatique dans le genre Pisum L : effet du génotype, de la nature de l'explant et du milieu de culture. L'aptitude à l'embryogenèse somatique a été estimée chez neuf pois potagers, onze pois protéagineux, deux pois fourragers et sept espèces ou sous-espèces autres que Pisum sativum $L$ en utilisant des apex de jeunes plantes, des cotylédons immatures ou des axes embryonnaires prélevés sur des graines mûres. Chacun des deux premiers types d'explants a été cultivé sur deux milieux qui diffèrent principalement par leur teneur en sucre. Le nombre d'embryons somatiques a varié considérablement avec le génotype, le type d'explants et le milieu de culture. Les axes embryonnaires ont produit moins d'embryons que les apex ou les cotylédons immatures. Dans l'ensemble, sept pois potagers sur neuf ont été plus embryogènes que l'ensemble des pois protéagineux. La nature du sucre apporté dans le milieu de culture a eu un rôle déterminant dans l'embryogenèse somatique chez le pois : l'apport de fructose au lieu du saccharose a permis une augmentation du rendement en embryons à partir d'apex pour 22 génotypes sur les 29 testés. De même, le remplacement du saccharose par du maltose a favorisé l'embryogenèse à partir de cotylédons immatures pour 20 génotypes sur les 29 testés.

pisum / embryogenèse somatique / génotype / sucre

* Correspondence and reprints 


\section{INTRODUCTION}

Somatic embryogenesis is a physiological process connected with cellular totipotency and is consequently specific to the plant kingdom. In vitro somatic embryogenesis has been achieved in numerous species but the experimental protocol has to be adapted to the species (Ammirato, 1983). Moreover, within each species, a strong genotypic effect is frequently observed and, in most cases, the genetic mechanism of plant regeneration remains unknown. Some reports concerning somatic embryogenesis in Medicago sp (Wan et al, 1988) and Zea mays L (Cowen et al, 1992) suggested that few genes were involved in somatic embryogenic ability. Genotype $x$ culture medium interactions were shown in Medicago sp (Wan et al, 1988), Glycine $\max L$ (Mer) (Komatsuda et al, 1991), Zea mays $L$ (Duncan et al, 1985) and Oryza sativa $L$ (Hartke and Lörz, 1989).

Transgenic plant recovery has been performed in pea after coculture with agrobacteria and shoot regeneration but these protocols were not sufficiently effective (Puonti-Kaerlas, 1993). In this context, somatic embryogenesis could appear as an interesting alternative to adventitious bud formation. Somatic embryogenesis in pea has been routinely achieved from shoot apices and immature zygotic embryos (Kysely et al, 1987; Kysely and Jacobsen, 1990). The number of somatic embryos per cultured explant varied with genotype (Kysely et al, 1987; Kysely and Jacobsen, 1990. Tétu et al, 1990; Stejskal and Griga, 1992; Van Doorne et al, 1995) but remained low. Consequently, we have undertaken studies in order to improve somatic embryo regeneration from shoot apices, immature cotyledons and embryonic axes. We have shown in previous studies that from four carbohydrates (sucrose, maltose, glucose, fructose) used at various concentrations (28 to $252 \mathrm{mM}$ for the disaccharides and 28 to $504 \mathrm{mM}$ for the monosaccharides), fructose at $336 \mathrm{mM}$ allowed the highest production of somatic embryos in cultures of shoot apices using the genotype $\mathrm{Cl} 830$ : the number of somatic embryos was three- to fourfold higher on $336 \mathrm{mM}$ fructose-containing medium compared to control (sucrose at $84 \mathrm{mM}$ ). In addition, the most effective auxins were 2,4-D, 4-CPA and picloram, the later being less detrimental to embryo development (Loiseau et al, 1995). Furthermore, the number of somatic embryos per cultured explant has been increased twofold when immature cotyledons (genotype $\mathrm{Cl} 830$ ) were cultured on a medium supplemented with maltose at $168 \mathrm{mM}$ compared to sucrose at 84 $\mathrm{mM}$. It should be observed that no interaction existed between the nature of the auxin (2,4-D or picloram) and the carbohydrate supply (Loiseau, 1996). Lastly, the highest production of somatic embryos from embryonic axes excised from mature seeds was obtained on a medium containing picloram at $22.5 \mu \mathrm{M}$, no other sugar being more effective than sucrose at $84 \mathrm{mM}$ (Loiseau, 1996).

For successful application of the tissue culture technique to crop breeding, routine plant regeneration must be achieved from several genotypes. Consequently, we have estimated the somatic embryogenic ability in a large range of genotypes, using three explant sources, and verified that the promotive effect of fructose and maltose on somatic embryogenesis in cultures of shoot apices and immature cotyledons respectively is not restricted to the genotype $\mathrm{Cl} 830$.

\section{MATERIAL AND METHODS}

\section{Plant material}

The 29 genotypes used in this study (table I) were kindly provided by Clause Semences (Brétigny-surOrge, France), GSP (Estrées-Mons, France), Florimond-Desprez (Cappelle-en-Pévèle, France), Blondeau (Bersée, France) and Pioneer Génétique (Oucques, France).

Shoot apices were excised from seven-day-old plants as previously described (Loiseau et al, 1995).

Immature cotyledons were obtained from plants grown in the field at Versailles (France) between March and July 1994. Two to three weeks after pollination, immature pods were harvested, surface-sterilized with $70 \%$ ethanol for $1 \mathrm{~min}$ and a Bayrochlor solution ( 3 g.L-1 available chlorine) for $30 \mathrm{~min}$ and rinsed three times with sterile deionized water. Just before culture initiation, immature seeds were excised from pods and the testa and the embryonic axis removed to leave the cotyledons. At this time, the embryos were approximatly at the beginning of the filling phase, the liquid endosperm being completely resorbed. The immature cotyledons were immediately placed in Petri dishes, the adaxial (flat) side facing the culture medium.

Embryonic axes were excised from mature seeds, after surface-sterilization as above and imbibition in sterile distilled water for approximatly $15 \mathrm{~h}$. The testa was removed and the embryonic axis, with the two axillary meristems of the cotyledonary node, was isolated and plated on the culture medium. 
Table I. Genotypes used in this study with their phenotypic characteristics.

Genotype (abbreviation)

Genotype (abbreviation)

\section{Garden peas}

$\begin{array}{ll}\text { Cl 830 } & \text { (830) } \\ \text { CAF ST 71 } & \text { (CAF) } \\ \text { Bikini } & \text { (BIK) } \\ \text { Filigreen } & \text { (FIL) } \\ \text { Hussar } & \text { (HUS) } \\ \text { Poppet } & \text { (POP) } \\ \text { Stampede } & \text { (STA) } \\ \text { Krilla } & \text { (KRI) } \\ \text { Twiggy } & \text { (TWI) }\end{array}$

\section{Field peas}

$\begin{array}{ll}\text { Diabolo } & \text { (DIA) } \\ \text { Baccara } & \text { (BAC) } \\ \text { Champion } & \text { (CHA) } \\ \text { Alex } & \text { (ALE) } \\ \text { Fluo } & \text { (FLU) } \\ \text { Choque } & \text { (CHO) } \\ \text { Amadeus } & \text { (AMA) } \\ \text { Ascona } & \text { (ASC) } \\ \text { Ballet } & \text { (BAL) } \\ \text { Tipu } & \text { (TIP) } \\ \text { Madria } & \text { (MAD) }\end{array}$

Forage peas

Golf
Rosakrone

(GOI)

(ROS)

Other species or subspecies

$\begin{array}{ll}P \text { arvense } & \text { (arv) } \\ P \text { elatius } & \text { (ela) } \\ P \text { axiphium } & \text { (axi) } \\ P \text { speciosum } & \text { (spe) } \\ P \text { mesomelan } & \text { (mes) } \\ P \text { transcaucasicum } & \text { (tra) } \\ P \text { abyssinicum } & \text { (aby) }\end{array}$

Origin
$(S p / 1)$$\quad$ af $2 \quad t a^{3}$

Origin
(Sp/l)

France (a)
France (a)
USA (b)
$?$ (b)
UK (b)
UK (b)
USA (b)
USA (b)
USA (e)

+
+
+
+
+
+
+
+
+

+
+
+
-
-
-
-
-
-

Green
Green
Yellow
Green
Green
Green
Green
Green
Green

Colour of cotyledons

Seed weight

$(g \times 1000)$

ror $w$ seeds 4

1 Suppliers: a, Clause Semences (Brétigny-sur-Orge, France); b, GSP (Estrées-Mons, France); c, Florimond-Desprez (Cappelle-enPélève, France); d, Blondeau (Bersée, France); e, Pioneer Génétique (Oucques, France). 2 Presence $(+$ ) or absence (-) of af mutation (leaflets converted to tendrils). ${ }^{3}$ Presence $(+)$ or absence $(-)$ of fa mutation (fasciated plants). ${ }^{4}$ Round ( $r$ ) or wrinkled (w) seeds.

\section{Tissue culture}

The basal medium was composed of MS salts (Murashige and Skoog, 1962), B5 vitamins (Gamborg et al, 1968), $84 \mathrm{mM}$ sucrose and $0.7 \%$ agar (Biofit, OSI, France). The $\mathrm{pH}$ was adjusted to 5.7 prior to autoclaving $\left(115^{\circ} \mathrm{C}, 20 \mathrm{~min}\right)$. The shoot apices of the 29 genotypes were cultured on two media (table II). The first one, named DS, was the basal medium supplemented with $4.5 \mu \mathrm{M}$ 2,4-dichlorophenoxyacetic acid (2,4-D). The composition of the second medium, named PF, has been optimized by the supply of fruc- tose at $336 \mathrm{mM}$ instead of sucrose at $84 \mathrm{mM}$. Immature cotyledons were also cultured on two media (table II). In the PS medium, picloram at $4.5 \mu \mathrm{M}$ was added to the basal medium. The other medium (PM) formulation had been optimized for somatic embryogenesis from $\mathrm{Cl} 830$ immature cotyledons (Loiseau, 1996) with maltose at $168 \mathrm{mM}$ substituting sucrose. Embryonic axes were cultured on a basal medium (EA) containing $22.5 \mu \mathrm{M}$ picloram.

Cultures were carried out in $55 \times 15 \mathrm{~mm}$ Petri dishes containing five explants on $5 \mathrm{~mL}$ of culture medium (25 explants per experiment), under a 16-h photoperiod $\left(10 \mu \mathrm{mol} \mathrm{m} \mathrm{m}^{-2} . \mathrm{s}^{-1}\right.$ from a mixture of Sylvania Grolux, 
Claude 'Lumière du jour' and Durotest 'True-lite') at $23^{\circ} \mathrm{C}$. The experiments concerning shoot apices and embryonic axes were repeated once. The shoot apices were maintained on the same medium for nine weeks, whereas immature cotyledon and embryonic axis cultures went of for five weeks. After these dates, callus necrosis began. At the end of the culture, the numbers of somatic embryos per cultured explant were recorded.

\section{RESULTS}

\section{Shoot apices}

Callogenesis began after two or three weeks. All genotypes, except $P$ arvense, produced compact calli, the colour of which varied between yellowish and green depending on the genotype. The composition of the culture medium had no effect on production, colour or compactness of the callus. The first somatic embryos appeared during the third week of culture. The number of somatic embryos per cultured explant varied widely with genotype and culture medium (fig 1) and was also independent of texture and colour of the callus. Whether embryo production was abundant or not, somatic embryos appeared asynchronously: after three weeks of culture, embryos could be formed continuously. On DS medium, the most productive genotypes were $\mathrm{Cl} 830$, CAFST $71, P$ arvense and $P$ elatius. Krilla, Twiggy, Golf and
Ascona were not embryogenic and the 21 other genotypes formed few embryos $(0.02-0.56$ embryo per cultured explant). Most of the genotypes produced more embryos on PF medium than on DS medium (fig 1), but Krilla and Twiggy remained poorly embryogenic. In the same way, somatic embryogenesis in Diabolo, Choque, $P$ speciosum, $P$ mesomelan and $P$ transcaucasicum was not affected by medium modification. The most productive genotypes on DS medium saw their productivity multiplied by 2 ( $P$ elatius), 2.4 (CAFST 71), 3.1 (Cl 830) and $4.7(P$ arvense). The productivity of $P$ axiphium was greatly increased: only 0.17 embryo was formed per explant cultured on DS whereas 6.95 embryos per cultured explant were formed on PF medium. Thus, there was a genotype $x$ culture medium interaction: some genotypes were poorly embryogenic on both media whereas others, such as $P$ axiphium, produced more embryos on fructose-containing medium than on saccharosecontaining medium.

Most of the genotypes (22 out of 29) produced more somatic embryos when fructose at $336 \mathrm{mM}$ substituted sucrose. It should be pointed out that fructose enhanced somatic embryo production without impairing embryo development: with the four most productive genotypes on DS medium, $40-60 \%$ of the embryos remained at the globular stage, whereas on PF, about $70 \%$ of the embryos reached the torpedo-shaped and cotyledonary stages.

Table II. Composition of media for the culture of the three types of explants.

Constituent

Mineral salts

Vitamins

Carbohydrate

Growth

regulator

Agar

$\mathrm{pH}$
Media for culture of shoot apices

$D S$

$$
\text { PF }
$$

Medium for culture of immature cotyledons

PS PM
Medium for culture of embryonic axes (EA)
MS

B5

MS

MS

B5

B52

Fructose
$(336 \mathrm{mM})$

Sucrose

(84 mM)

Maltose

(168 mM)

Sucrose

(84 mM)

Picloram

Picloram

(4.5 $\mu \mathrm{M})$

$(4.5 \mu \mathrm{M})$

Picloram

$(4.5 \mu \mathrm{M})$

Picloram

$(22.5 \mu \mathrm{M})$

$0.7 \%$

$0.7 \%$

$0.7 \%$ 


\section{A. DS medium}

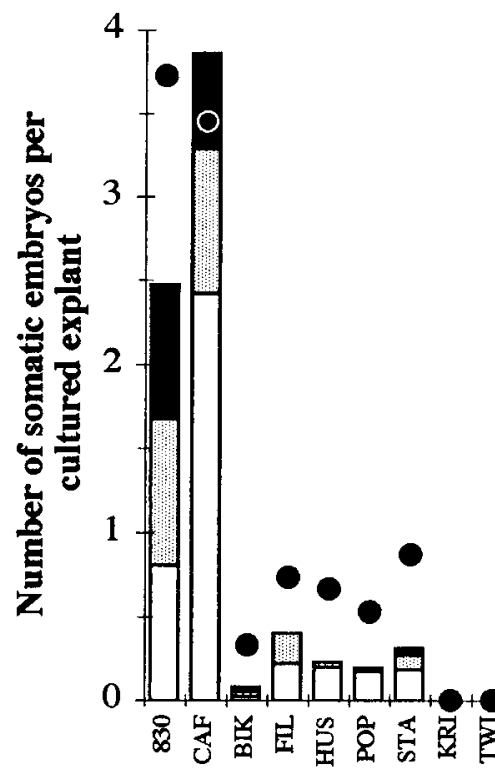

DEVELOPMENTAL STAGES
OF SOMATIC EMBRYOS

-COTYLEDONARY $\bullet \%$ embryogenic explants

GTORPEDO

口GLOBULAR

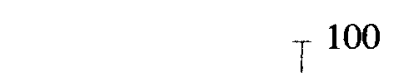

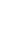
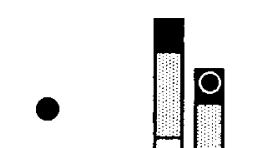

\section{B. PF medium}

要
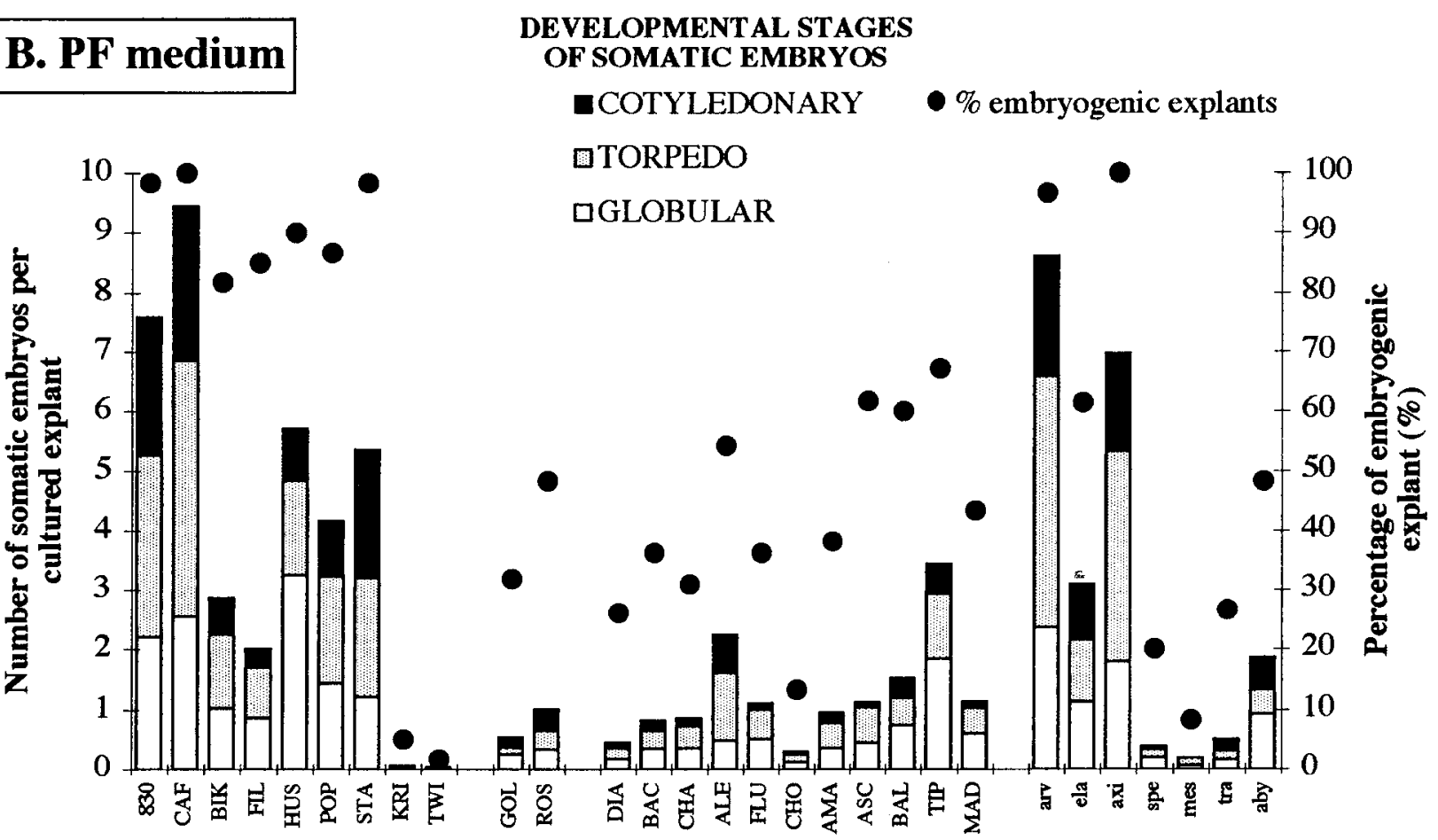

Genotypes

Fig 1. Somatic embryogenesis from shoot apices in a range of 29 Pisum cultivars or species. The numbers of globular, torpedo and cotyledonary somatic embryos per cultured explant were recorded after 9 weeks on DS medium (A) or PF medium (B). Data are the mean of two independent experiments. 


\section{Immature cotyledons}

During the first week of culture, the cotyledons enlarged but no cell proliferation was visible. Callus began to grow in the wounded area caused by the excision of the axis after 10-15 days of culture. All genotypes produced compact calli whose colour varied between yellow and green depending on genotype, as previously noted in shoot apex cultures. Exogenous sugar supply did not influence texture and colour of the

\section{A. PS medium}

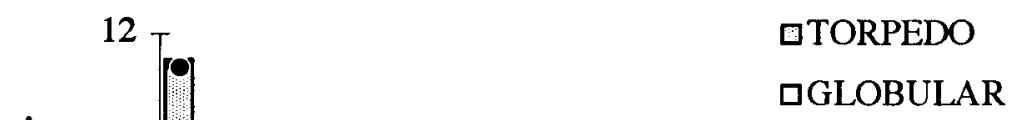

DEVELOPMENTAL STAGES

OF SOMATICEMBRYOS

-COTYLEDONARY $\bullet \%$ embryogenic explants

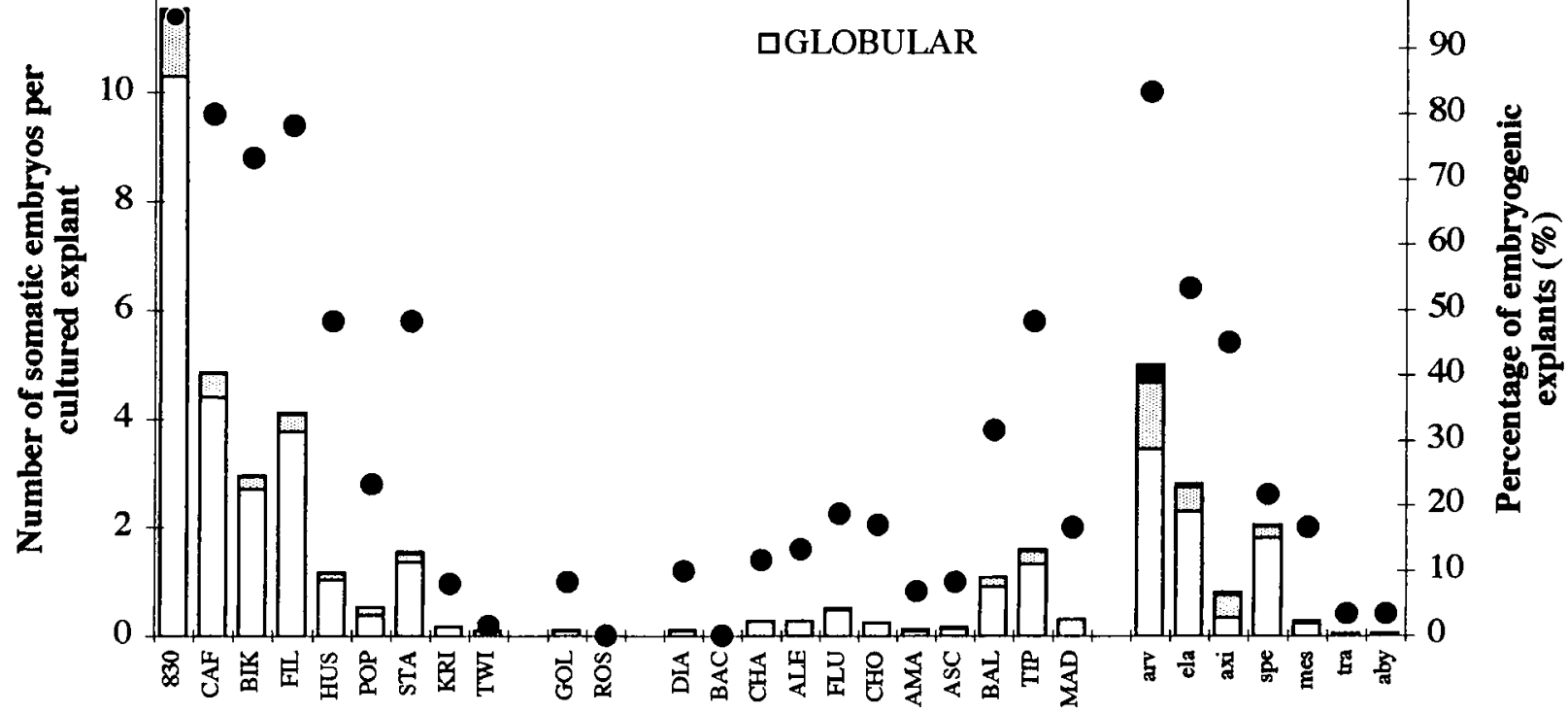

Genotypes

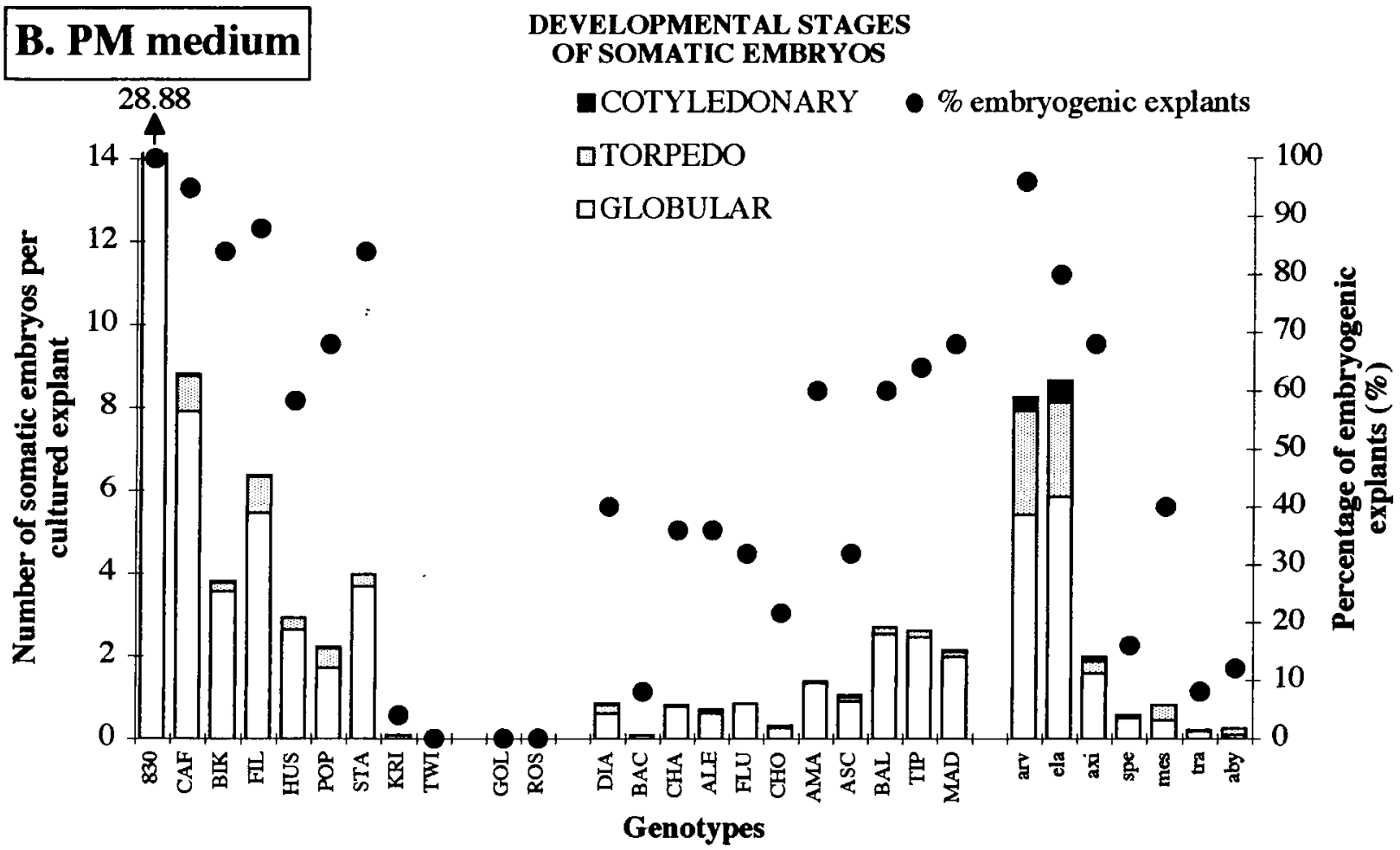

Fig 2. Somatic embryogenesis from immature cotyledons in a range of 29 Pisum cultivars or species. The numbers of globular, torpedo and cotyledonary somatic embryos per cultured explant were recorded after 5 weeks on PS medium (A) or PM medium (B). 


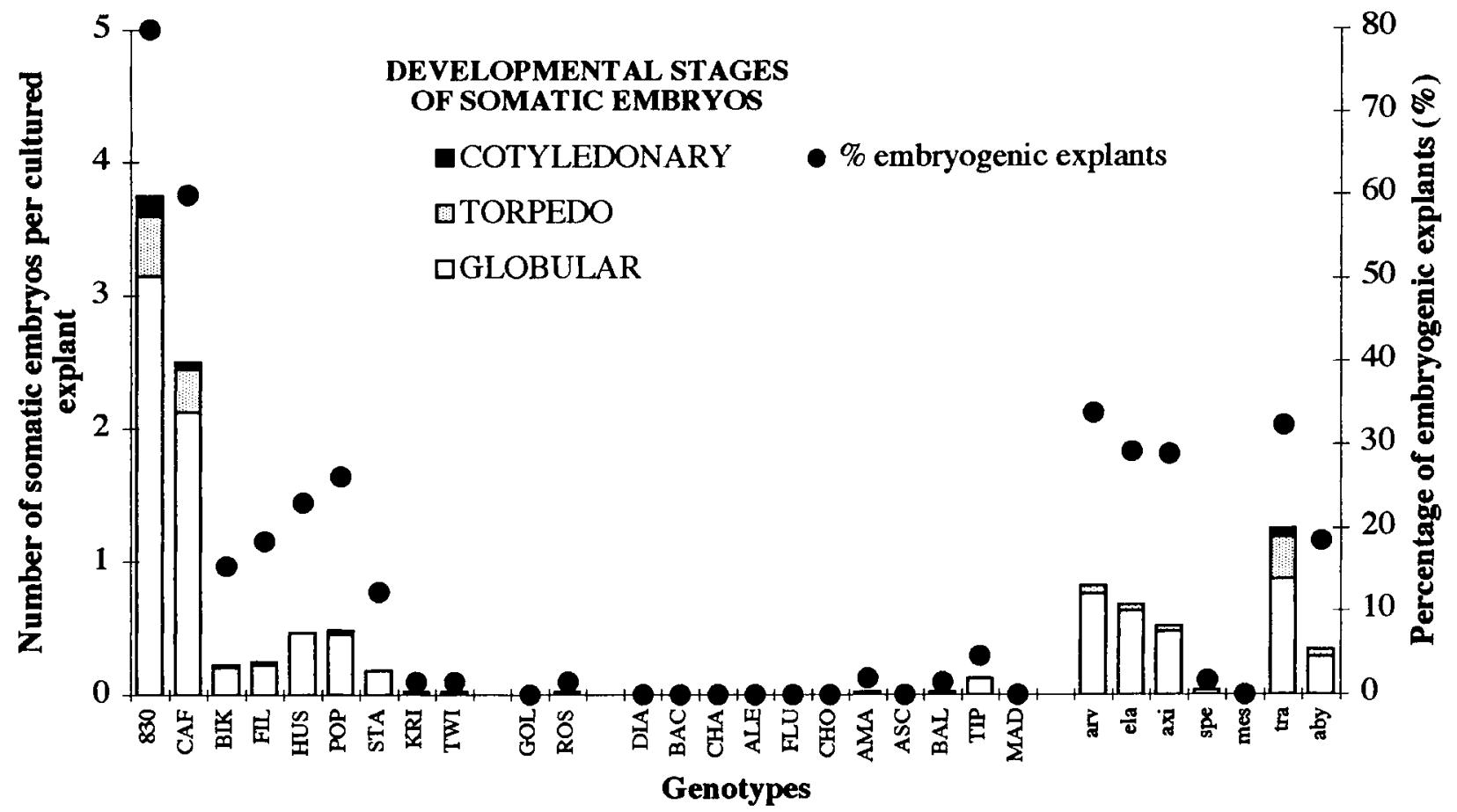

Fig 3. Somatic embryogenesis from embryonic axes in a range of 29 Pisum cultivars or species. The numbers of globular, torpedo and cotyledonary somatic embryos per cultured explant were recorded after 5 weeks on EA medium. Data are the mean of two independent experiments.

calli. The first somatic embryos appeared during the first week of culture. Embryo differentiation was more synchronous than with shoot apices: at the end of the fourth week, the formation and the development of the somatic embryos were over. Whatever the genotype, somatic embryogenesis occured on the callus, at the proximal end of the cotyledon, on the abaxial side, rarely on the side facing the culture medium. $\mathrm{Cl} 830$ was widely more embryogenic than the other genotypes (fig 2). For 20 genotypes, the supply of maltose increased the number of somatic embryos per cultured explant. Among the best genotypes on PS medium, the productivity of $\mathrm{Cl} 830$ was multiplied by 2.5 on PM medium and that of CAFST 71, $P$ arvense, Filigreen and Bikini was multiplied by $1.3-1.8$. The productivity of $P$ elatius was increased threefold on maltose-containing medium. On the other hand, for nine genotypes (Krilla, Twiggy, Golf, Rosakrone, Baccara, Choque, $P$ speciosum, $P$ transcaucasicum, $P$ abyssinicum), the use of maltose instead of sucrose did not promote somatic embryogenesis and even reduced it in $P$ speciosum. The production of somatic embryos was higher on PM medium compared to PS medium in $P$ transcaucasicum and $P$ abyssinicum but the number of somatic embryos remained low (fig 2). Substituting maltose to sucrose resulted in a moderate but real increase in production of somatic embryos for 20 geno- types out of 29 tested. Whatever the sugar, most of the embryos remained in the globular stage. This was a feature common to the genotypes.

\section{Embryonic axis culture}

A compact, generally not abundant callus appeared during the second week of culture, from the wounded areas caused by the excision of the cotyledons. The colour of this callus varied between yellow and green according to genotype, irrespective of embryogenic ability. Cell proliferation could also occur on the root during the third week. The first somatic embryos were formed after 3-4 weeks of culture in the preexisting axillary meristem area of the cotyledonary node. Some somatic embryos could also appear on the shoot apex of the axis. Embryonic axes were less embryogenic than both other explants. In addition, about $80 \%$ of the somatic embryos remained in the globular stage. $\mathrm{Cl} 830$ was the most productive genotype (fig 3 ). CAFST 71 and $P$ transcaucasicum were also rather embryogenic and the other 26 genotypes were poorly or not embryogenic. In general, forage peas and field peas, except Tipu, were not embryogenic. 


\section{DISCUSSION}

Regardless of culture medium and explant, all genotypes were able to produce at least one embryo. Nevertheless, two garden pea cultivars (Krilla, Twiggy), one forage pea (Golf) and one field pea (Choque) always formed less than 0.5 embryo per cultured explant. It should be pointed out that the field pea cultivars used in this study, except Tipu, are genetically linked: all include some germplasm from the cr Finale in their genetic background. Ranch (1993) explained the low genotypic effects often observed in soybean somatic embryogenesis by a narrow genetic basis. We also have to note that $\mathrm{Cl} 830$ and CAF ST 71, which expressed relatively high embryogenic potential regardless of explant nature and culture medium, are genetically linked: CAF ST 71 descends from a cross with $\mathrm{Cl} 830$ as one parent. The most productive genotypes on the non-optimized media also gave the highest response on the optimized media, although genotype $x$ culture medium interactions occurred. Shoot apices of $P$ axiphium and immature cotyledons of $P$ elatius were particularly responsive to the modification of the medium. Such genotype $x$ culture medium interactions were previously described in alfalfa (Wan et al, 1988) and soybean (Komatsuda et al, 1991). Some nonembryogenic genotypes on the non-optimized medium have produced few somatic embryos on the optimized medium. This was the case for cultures of shoot apices in Krilla, Twiggy, Golf and Ascona and cultures of cotyledons in Baccara. Within the Gramineae, Vasil (1987) assumed that differences in regenerative ability between genotypes may be caused by different physiological states rather than genetic factors. This was not the case in our experiments, at least for the cultures of cotyledons: whatever the genotype, younger or older cotyledons were no more embryogenic than those used in the present study, and the relative ability of each genotype was unchanged (data not shown).

Embryonic axes gave poor results and attempts to enhance their productivity failed (Loiseau, 1996). This could be caused by hypoxic pretreatment of tissues during the imbibition of seeds. The stimulation of somatic embryogenesis in shoot apex or immature cotyledon caused by substituting fructose or maltose to sucrose as previously shown with $\mathrm{Cl} 830$ (Loiseau et al, 1995), was confirmed here with 22 genotypes out of 29 for cultures of shoot apices and 20 genotypes out of 29 for cultures of immature cotyle- dons. This shows that the crucial role of exogenous carbohydrate in somatic embryogenesis in pea was not a particularity of $\mathrm{Cl} 830$. High sugar concentrations have been also required for somatic embryogenesis in Helianthus annuus $L$ (Finer, 1987), Panax ginseng (CA Meyer) (Asaka et al, 1994) and for somatic embryo development in Picea mariana (Mill) BSP and Picea rubens Sarg (Tremblay and Tremblay, 1991). Sugars have acted as osmotic agent, at least in part, when their concentrations were high (Denchev et al, 1991; Tremblay and Tremblay, 1991). In the cultures of shoot apices of $\mathrm{Cl} 830$, glucose at 336 $\mathrm{mM}$ and sucrose or maltose at $168 \mathrm{mM}$ were less effective than fructose at $336 \mathrm{mM}$ (Loiseau et al, 1995). In addition, sucrose, fructose or glucose at $168 \mathrm{mM}$ reduced the production of somatic embryos compared to maltose at the same concentration in culture of immature cotyledons (Loiseau, 1996). Consequently, the promotive effect of fructose at $336 \mathrm{mM}$ and maltose at 168 $\mathrm{mM}$ compared to sucrose at $84 \mathrm{mM}$, in cultures of shoot apices and immature cotyledons respectively, was linked to the nature of carbohydrate rather than to the osmotic potential of the culture medium. Fructose has not been frequently introduced in media used to sustain somatic embryogenesis. Fructose has enhanced somatic embryo production in Rosa rugosa Thunb (Kunitake et al, 1993) and embryo development in Picea rubens Sarg (Tremblay and Tremblay, 1991). The promotive effect of maltose on embryo production has been demonstrated in soybean (Ranch et al, 1986), alfalfa (Strickland et al, 1987) and in anther and microspore cultures (Batty and Dunwell, 1989; Scott and Lyne, 1994). Knowing the pivotal role played by exogenous sugar in somatic embryogenesis in pea, we could suspect differences in the metabolism of carbohydrates between genotypes. It can be underlined that garden pea cultivars (except Krilla and Twiggy), which on average show a better embryogenic response than field peas, also present a wrinkled seed type, more frequently associated with higher soluble sugar content and lower starch content than round seeds (Strickland and Wilson, 1983). In addition, Wang et al (1987) showed that the $r$ locus had a clear effect on water content and osmotic potential in immature cotyledons, in vivo as well as in vitro. Thus, it may be interesting to undertake biochemical studies concerning enzyme activity involved in carbohydrate metabolism during cultures of shoot apices and immature cotyledons within a range of genotypes.

Whatever the genotypes or the explants, the protocols have to be improved in order to obtain 
calli composed in a large part by embryogenic cells, and to increase the number of cotyledonary embryos. Nevertheless, this system allowed plant recovery (Loiseau, 1996; Loiseau et al, 1995) and it may be suitable for transgenic plant regeneration. In addition, it is now possible to study the genetic control of somatic embryogenesis in pea, as was done earlier (Bencheikh, 1992).

\section{ACKNOWLEDGMENTS}

This work was supported by the Union nationale interprofessionnelle des plantes riches en protéines (Paris, France). We gratefully acknowledge the assistance of $\mathrm{J}$ Lebœuf in growing the plant material.

\section{REFERENCES}

Ammirato PV (1983) Embryogenesis. In: Handbook of Plant Cell Culture 1 (DA Evans, WR Sharp, PV Ammirato, Y Yamada, eds), Macmillan, New York, 82-123

Asaka I, li I, Hirotani M, Asada Y, Yoshikawa T, Furuya $T$ (1994) Mass production of ginseng (Panax ginseng) embryoids on media containing high concentrations of sugar. Plant Med 60, 146-148

Batty N, Dunwell J (1989) Effect of maltose on the response of potato anthers in culture. Plant Cell Tiss Org Cult 18, 221-226

Bencheikh M (1992) Contribution à l'étude des bases génétiques de l'aptitude à l'embryogenèse somatique chez le pois (Pisum sativum $L$ et Pisum arvense $\mathrm{L}$ ). Thèse Doctorat, institut National Agronomique Paris-Grignon, $101 \mathrm{p}$

Cowen NM, Johnson CD, Armstrong K, Miller $M$, Woosley A, Pescitelli S, Skokut M, Belmar S, Petolino JF (1992) Mapping genes conditioning in vitro androgenesis in maize using RFLP analysis. Theor Appl Genet 84, 720-724

Denchev PD, Velcheva M, Atanassov Al (1991) A new approach to direct somatic embryogenesis in Medicago. Plant Cell Rep 10, 338-341

Duncan DR, Williams ME, Zehr BE, Wildhom JM (1985) The production of callus capable of plant regeneration from immature embryos of numerous Zea mays genotypes. Planta 165, 322-332

Finer JJ (1987) Direct somatic embryogenesis and plant regeneration from immature embryos of hybrid sunflower (Helianthus annuus L) on a high sucrosecontaining medium. Plant Cell Rep 6, 372-374

Gamborg OL, Miller RA, Ojima K (1968) Nutrient requirements of suspension cultures of soybean root cells. Exp Cell Res 50, 151-158

Hartke S, Lörz H (1989) Somatic embryogenesis and plant regeneration from various indica rice (Oryza sativa L) genotypes. J Genet Breed 43, 205-214
Komatsuda T, Kaneko K, Oka S (1991) Genotype x sucrose interactions for somatic embryogenesis in soybean. Crop Sci 31, 333-337

Kunitake H, Imamizo H, Mii M (1993) Somatic embryogenesis and plant regeneration from immature seed-derived calli of rugosa rose (Rosa rugosa Thunb). Plant Sci 90, 187-194

Kysely W, Jacobsen HJ (1990) Somatic embryogenesis from pea embryos and shoot apices. Plant Cell Tiss Org Cult 20, 7-14

Kysely W, Myers JR, Lazzeri PA, Collins GB, Jacobsen HJ (1987) Plant regeneration via somatic embryogenesis in pea (Pisum sativum L). Plant Cell Rep 6, 305-308

Loiseau J (1996) Contribution à l'étude des facteurs améliorant l'embryogenèse somatique chez le pois (Pisum sativum L). Thèse Doctorat, Université Paris-Sud, $n^{\circ}$ 4037, $133 p$

Loiseau J, Marche C, Le Deunff Y (1995) Effects of auxins, cytokinins, carbohydrates and amino acids on somatic embryogenesis induction from shoot apices of pea. Plant Cell Tiss Org Cult 41, 267-275

Murashige T, Skoog F (1962) A revised medium for rapid growth and bioassays with tobacco tissue cultures. Physiol Plant 15, 473-497

Puonti-Kaerlas $J$ (1993) Genetic engineering in pea crop improvement. Acta Agric Scand Sect B Soil Plant Sci 43, 65-73

Ranch JP (1993) The potential for synthetic soybean seed. In: Synseeds. Applications of Synthetic Seeds to Crop Improvements (K Redenbaugh, ed), CRC Press, Boca Raton, 329-350

Ranch JP, Ogelsby L, Zielinski AC (1986) Plant regeneration from tissue cultures of soybean by somatic embryogenesis. In: Cell Culture and Somatic Cell of Plants 3 (IK Vasil, ed), Academic Press, Orlando, 97-110

Scott P, Lyne RL (1994) The effect of different carbohydrate sources upon the initiation of embryogenesis from barley microspores. Plant Cell Tiss Org Cult 36, 129-133

Stejskal J, Griga M (1992) Somatic embryogenesis and plant regeneration in Pisum sativum L. Biol Plant 34, 15-22

Strickland SG, Nichol JW, McCall CM, Stuart DA (1987) Effect of carbohydrate source on alfalfa somatic embryogenesis. Plant Sci 48, 113-121

Strickland RG, Wilson KE (1983) Sugars and starch in developing round and wrinkled pea seeds. Ann Bot 52, 919-921

Tétu T, Sangwan RS, Sangwan-Norreel BS (1990) Direct somatic embryogenesis and organogenesis in cultured immature zygotic embryos of Pisum sativum L. J Plant Physiol 137, 102-109

Tremblay L, Tremblay FM (1991) Carbohydrate requirements for the development of black spruce (Picea mariana (Mill) BSP) and red spruce ( $P$ rubens Sarg) somatic embryos. Plant Cell Tiss Org Cult 27, 95-103 
Van Doorne LE, Marshall G, Kirkwood RC (1995) Somatic embryogenesis in pea (Pisum sativum $L$ ): effect of explant, genotype and culture conditions. Ann Appl Biol 126, 169-179

Vasil IK (1987) Developing cell and tissue culture systems for the improvement of cereal and grass crops. J Plant Physiol 128, 193-218
Wan Y, Sorensen EL, Liang GH (1988) Genetic control of in vitro regeneration in alfalfa (Medicago sativa L). Euphytica 39, 3-9

Wang TL, Smith CM, Cook SK, Ambrose MJ, Hedley CL (1987) An analysis of seed development in Pisum sativum, III The relationship between the $r$ locus, the water content and the osmotic potential of seed tissues in vivo and in vitro. Ann Bot 59, 73-80 